\title{
Register based monitoring shows decreasing socioeconomic differences in Finnish perinatal health
}

\author{
M Gissler, J Meriläinen, E Vuori, E Hemminki
}

J Epidemiol Community Health 2003;57:433-439

\begin{abstract}
Study objective: Several studies on differences in infant outcome by socioeconomic position have been done, but these have usually been based on ad hoc data linkages. The aim of this paper was to investigate whether socioeconomic differences in perinatal health in Finland could be regularly monitored using routinely collected data from one single register.

Design and setting: Since October 1990, the Finnish Medical Birth Register (MBR) has included data on maternal occupation. A special computer program that converted the occupation name into an occupational code and into a socioeconomic position was prepared. Perinatal health was measured with five different indicators. The Finnish MBR data for years 1991 to 1999 (n=565 863 newborns) were used in the study. The study period was divided into three, three year periods to study time trends. Results: An occupational code was derived for $95 \%$ of women, but it was not possible to define a socioeconomic position for $22 \%$ of women, including, for example, students and housewives (the group "Others"). For the rest, the data showed socioeconomic differences in all perinatal health indicators. Maternal smoking explained up to half of the excess risk for adverse perinatal outcome in the lowest socioeconomic group. The socioeconomic differences narrowed during the 1990s: infant outcome improved in the lowest socioeconomic group, but remained at the same level or even deteriorated in other groups. When comparing the lowest group with the highest group, the odds ratios (OR) adjusted for maternal background characteristics at least halved for prematurity (from 1.32 (95\% confidence intervals 1.24 to 1.43 ) in 1991-1993 to 1.16 (1.08 to 1.25) in 1997-1999), for low birth weight (from 1.49 (1.36 to 1.63 ) to 1.25 (1.17 to 1.40$)$ ), and for perinatal mortality (from 1.79 (1.44 to 2.21$)$ to 1.33 (1.07 to 1.66$)$ ).

Conclusions: Social inequality in perinatal health outcomes exists in Finland, but seems to have diminished in the 1990s. These data showed that routinely collected birth register data provide a good source for studies on socioeconomic health differences in the perinatal period, but that uncertainty, mainly attributable to the large group of women with difficult to classify socioeconomic status, remains.
\end{abstract}

S ocioeconomic health differences have been studied widely in all Nordic countries. The Nordic welfare societies have declared an aim to diminish social health inequality, but socioeconomic differences in mortality, morbidity, and the utilisation of healthcare services among the general populations have been reported for all these countries in the 1980s and 1990s. ${ }^{1}$ This is also true as regards perinatal and childhood health. According to previous Finnish studies based on data for the 1987-1993 period, there is increased risk for adverse infant outcome among unmarried women, ${ }^{2}$ among women with short education ${ }^{3}$ and among women with low socioeconomic status as defined by maternal occupation. ${ }^{56}$

After a steep economic recession in the early 1990s, Finland experienced a boom economy that substantially enlarged differences in income distribution. ${ }^{7}$ This, along with continuously high unemployment rates, may have widened socioeconomic health differences. Compared with the previous decade, the socioeconomic differences in mortality intensified in the 1990s, mainly because of increased mortality attributable to cardiovascular diseases and increased use of alcohol in the lowest socioeconomic groups. ${ }^{8}$ In contrast, the differences in morbidity did not change. ${ }^{9}$ The trends regarding socioeconomic differences in perinatal health have not been investigated after the early 1990s.

Studies on socioeconomic differences require large datasets. Collection of ad hoc research data tends to be expensive and time consuming, ${ }^{10}$ which decreases the feasibility of their use in such studies. National administrative health registers provide an alternative data source, ${ }^{11}{ }^{12}$ but they usually include only limited background information. In the most extreme case only data on age, sex, and residence are collected. ${ }^{13}$ In Finland, this limitation can be bypassed with data linkage to other sources, such as the Central Population Register, which contains information on occupation, ${ }^{5}$ and to the Education Register, ${ }^{3}$ the Taxation Register, ${ }^{14}$ and census data, which include several variables related to living conditions. ${ }^{15}$ Even though the existence of a nationwide person identification system makes such data linkage technically comparatively easy, it may be administratively complicated and expensive. ${ }^{16}$ In addition, data linkage has to be done in a research context, and routine linkage is prohibited by the Finnish data protection legislation.

Since October 1990, the Finnish Medical Birth Register (MBR) has included information on the mother's occupation at the time of birth. The aim of this study was to investigate the feasibility of using that information in studying socioeconomic differences in perinatal health by using the 1991-1999 MBR with information on more than 565000 newborns. We also wanted to test, whether socioeconomic differences increased among newborns in Finland in the 1990s, as was the case with socioeconomic differences in mortality among the adult population. ${ }^{8}$

\section{METHODS}

The MBR was started in 1987 and it is run by the National Research and Development Centre for Welfare and Health. The register includes information on maternal background, on 
Table 1 Parturients by socioeconomic groups, Finland, 1991-1999, \%

\begin{tabular}{|c|c|c|c|c|c|c|}
\hline & & 1991-1993 & 1994-1996 & 1997-1999 & 1991-1999 & Number \\
\hline 1 & Upper white collar workers & 14.2 & 15.3 & 15.9 & 15.1 & 84175 \\
\hline$\|$ & Lower white collar workers & 48.0 & 45.1 & 41.2 & 44.9 & 250391 \\
\hline III & Blue collar workers & 18.9 & 17.8 & 16.5 & 17.8 & 99040 \\
\hline \multirow[t]{9}{*}{0} & $\begin{array}{l}\text { Others } \\
\text { - of which }\end{array}$ & 18.9 & 21.8 & 26.4 & 22.2 & 123687 \\
\hline & Entrepreneurs & 0.9 & 0.9 & 1.0 & 0.9 & 5118 \\
\hline & Farmers & 1.0 & 1.0 & 1.0 & 1.0 & 5635 \\
\hline & Students & 5.0 & 6.9 & 7.5 & 6.4 & 35790 \\
\hline & Retired & 0.1 & 0.1 & 0.1 & 0.1 & 407 \\
\hline & Unemployed & 0.2 & 0.5 & 0.6 & 0.4 & 2292 \\
\hline & Housewives & 6.5 & 7.8 & 7.0 & 7.1 & 39582 \\
\hline & Unclassifiable & 1.7 & 0.6 & 2.8 & 1.7 & 9346 \\
\hline & Missing & 3.5 & 4.0 & 6.4 & 4.6 & 25465 \\
\hline Total & & 100.0 & 100.0 & 100.0 & 100.0 & 557293 \\
\hline
\end{tabular}

care and interventions during pregnancy and delivery, and on newborns' outcome until the age of seven days. The data are collected at all delivery hospitals, and in case of home births, by the assisting health care personnel. ${ }^{17}$ All live births and stillbirths with a gestational age of 22 weeks or more, or with a birth weight of 500 grammes or more, are included in the register. ${ }^{18}$ During the study period from 1991 to 1999, in total $74 \%$ of the data were received electronically, with an observed increase by time from $67 \%$ in 1991 to $82 \%$ in 1999 .

According to a 1991 data quality study, most of the MBR content corresponded well or satisfactorily with the hospital record data. The information on maternal occupation recorded in the MBR was in concordance with the hospital record data in $94 \%$ of cases, ${ }^{17}$ and when categorised into four broad social classes was in concordance for $96 \%$ of cases. ${ }^{19}$

SAS and SQL software were used to prepare a special computer program to transform the occupation name into an occupational code and subsequently into a socioeconomic grouping (table 1). Both codings were based on national standards by Statistics Finland..$^{20}{ }^{21}$ If only the highest education level was given instead of an occupation name, education was converted into a socioeconomic group according to the national classification on education. ${ }^{22}$ The socioeconomic groups were further aggregated into four groups: SES Group I included upper white collar workers, SES Group II included lower white collar workers, SES Group III included blue collar workers, and the SES Group "Others" included all other groups.

To study trends in socioeconomic differences, the study period was divided to three, three year periods: 1991-1993, 1994-1996, and 1997-1999.

The following indicators were used to monitor perinatal outcome: (1) the number of preterm births $(<37$ gestation weeks based on the best estimate at delivery) per 100 deliveries, (2) mean birth weight, (3) the number of low birthweight children (<2500 grammes) per 100 newborns, (4) the number of small for gestational age (SGA) children per 100 newborns (as defined by national standards for birth weight and gestational age ${ }^{23}$ ), and (5) perinatal deaths (early neonatal deaths for infant up to seven days of life and stillbirths of 22 gestation weeks or more or with a birth weight of 500 grammes or more) per 1000 newborns.

We used $t$ tests, the test for relative proportions, and $\chi^{2}$ tests to study differences in background variables and perinatal outcomes by socioeconomic group. The Breslow-Day test for heterogeneity and linear regression was used to study the trend by time period.

To adjust for differences in maternal background variables, adjusted odds ratios (OR) with $95 \%$ confidence intervals (CI) for differences by socioeconomic group were calculated. Two different multiple logistic regression models were utilised: In Model I, maternal age (continuous), parity defined as the number of previous deliveries (continuous) and mother's county of residence (six) were included as confounders. To investigate how much of the socioeconomic differences was caused by maternal smoking during pregnancy, Model II further included smoking (non-smoker, smoker, no information). The contribution of smoking to socioeconomic differences was measured by the percentage reduction between the ORs for model with smoking and the OR without smoking. ${ }^{24}$

For all logistic regressions, only data for singletons $(\mathrm{n}=548913)$ were used.

\section{RESULTS}

The feasibility of determining socioeconomic position

Creation of the program to change the occupation name into an occupational code and into a socioeconomic position was found to be challenging. For the 1991 data, all occupational codes were reviewed and entered manually into the occupational database, but subsequently only previously uncoded occupations had to be coded manually. However, information on occupation was written in Finnish and Swedish (the two official languages in Finland), and more recently increasingly also in English, which increased the work load related to coding. Furthermore, misspellings and the transfer of special characters, especially the Scandinavian letters, caused technical problems for the coding. These were solved by creating special double checking procedures to improve the quality of our program.

The final database had 25018 different occupations and their combinations, including misspellings. We were able to assign an occupational code to 21924 of these $(87.6 \%)$ and a socioeconomic group to 23335 (93.3\%). There were an additional 787 entries (3.1\%) for which only the highest education level was given, and we were able to convert 777 of them into socioeconomic status. Thus, the socioeconomic group was determined in total for 24112 occupations, or $96.4 \%$ of those included in the database. When calculating the successful determination per woman, an occupation code was defined for $95.4 \%$, and a socioeconomic group for $93.8 \%$ of women who were registered as having given birth.

During the study period the proportion of women in SES Group I increased (from 14\% to 16\%), while the proportions of those in SES Group II and in SES Group III decreased from $48 \%$ to $41 \%$ and from $19 \%$ to $17 \%$, respectively (table 1 ). The proportion of women in the SES Group "Others" increased from $19 \%$ to $26 \%$. One main reason was that the proportion of women giving birth who had no reported occupation increased from $3.5 \%$ to $6.4 \%$. Also the proportion of those 


\begin{tabular}{|c|c|c|c|c|c|c|c|c|c|c|}
\hline & & Total & & $1991-1993$ & & 1994-1996 & & 1997-1999 & & $\mathrm{p} \dagger$ \\
\hline Births (n) & & 557293 & & 196570 & & 187906 & & 172817 & & \\
\hline \multicolumn{11}{|c|}{ Maternal age, mean and SD, years } \\
\hline Upper white collar workers & I & 32.0 & 4.5 & 31.7 & 4.2 & 32.0 & 5.1 & 32.3 & 4.2 & 0.026 \\
\hline Lower white collar workers & ॥ & 30.1 & 4.8 & 29.5 & 4.8 & 30.2 & 4.7 & 30.6 & 5.0 & 0.094 \\
\hline Blue collar workers & III & 28.6 & 5.2 & 28.1 & 5.1 & 28.7 & 5.1 & 29.1 & 5.2 & 0.169 \\
\hline \multirow[t]{2}{*}{ Others } & 0 & 27.7 & 5.8 & 27.8 & 5.8 & 27.5 & 5.7 & 27.8 & 5.8 & 0.987 \\
\hline & Total & 29.6 & 5.0 & 29.3 & 5.0 & 29.6 & 5.1 & 29.9 & 5.1 & 0.080 \\
\hline \multicolumn{11}{|c|}{ Number of previous pregnancies, mean and SD } \\
\hline Upper white collar workers & 1 & 1.3 & 1.4 & 1.2 & 1.4 & 1.3 & 1.4 & 1.3 & 1.5 & 0.058 \\
\hline Lower white collar workers & ॥ & 1.4 & 1.6 & 1.4 & 1.5 & 1.4 & 1.5 & 1.5 & 1.7 & 0.070 \\
\hline Blue collar workers & III & 1.5 & 1.5 & 1.4 & 1.4 & 1.5 & 1.5 & 1.6 & 1.6 & 0.305 \\
\hline \multirow[t]{2}{*}{ Others } & 0 & 1.8 & 2.2 & 1.9 & 2.2 & 1.8 & 2.2 & 1.7 & 2.2 & 0.126 \\
\hline & Total & 1.5 & 1.7 & 1.5 & 1.6 & 1.5 & 1.7 & 1.5 & 1.7 & 0.005 \\
\hline \multicolumn{11}{|c|}{ Number of previous births, mean and SD } \\
\hline Upper white collar workers & I & 0.9 & 1.1 & 0.9 & 1.1 & 0.9 & 1.1 & 0.9 & 1.1 & 0.899 \\
\hline Lower white collar workers & ॥ & 1.0 & 1.2 & 1.0 & 1.2 & 1.0 & 1.2 & 1.1 & 1.3 & $<0.001$ \\
\hline Blue collar workers & III & 1.0 & 1.1 & 1.0 & 1.1 & 1.0 & 1.1 & 1.0 & 1.2 & 0.346 \\
\hline \multirow[t]{2}{*}{ Others } & 0 & 1.3 & 1.9 & 1.4 & 1.9 & 1.3 & 1.9 & 1.2 & 1.8 & 0.012 \\
\hline & Total & 1.1 & 1.3 & 1.0 & 1.3 & 1.1 & 1.3 & 1.1 & 1.4 & 0.306 \\
\hline \multicolumn{11}{|l|}{ Single mother, $\%$} \\
\hline Upper white collar workers & I & 5.0 & & 3.3 & & 6.3 & & 5.5 & & 0.118 \\
\hline Lower white collar workers & ॥ & 7.9 & & 5.1 & & 9.7 & & 9.1 & & $<0.001$ \\
\hline Blue collar workers & III & 12.9 & & 9.1 & & 15.6 & & 14.2 & & 0.004 \\
\hline \multirow[t]{2}{*}{ Others } & 0 & 10.3 & & 7.3 & & 12.2 & & 11.8 & & 0.002 \\
\hline & Total & 8.9 & & 6.0 & & 10.8 & & 10.1 & & 0.529 \\
\hline \multicolumn{11}{|l|}{ Smoked during pregnancy, $\%$} \\
\hline Upper white collar workers & 1 & 4.6 & & 5.5 & & 4.2 & & 4.1 & & $<0.001$ \\
\hline Lower white collar workers & ॥ & 13.0 & & 14.2 & & 12.6 & & 12.1 & & 0.475 \\
\hline Blue collar workers & III & 26.0 & & 28.2 & & 25.2 & & 24.5 & & $<0.001$ \\
\hline \multirow[t]{2}{*}{$\begin{array}{l}\text { Others } \\
\text { Others }\end{array}$} & 0 & 18.0 & & 18.1 & & 18.0 & & 17.9 & & $<0.001$ \\
\hline & Total & 15.2 & & 16.3 & & 14.7 & & 14.4 & & 0.314 \\
\hline \multicolumn{11}{|l|}{ Multiple birth, \% } \\
\hline Upper white collar workers & 1 & 1.8 & & 1.5 & & 1.8 & & 2.1 & & 0.158 \\
\hline Lower white collar workers & $\|$ & 1.6 & & 1.4 & & 1.6 & & 1.8 & & 0.063 \\
\hline Blue collar workers & III & 1.4 & & 1.4 & & 1.4 & & 1.5 & & 0.058 \\
\hline \multirow[t]{2}{*}{ Others } & 0 & 1.3 & & 1.2 & & 1.2 & & 1.4 & & 0.080 \\
\hline & Total & 1.5 & & 1.4 & & 1.5 & & 1.7 & & 0.076 \\
\hline
\end{tabular}

*All differences between the socioeconomic groups are statistically significant, $p<0.001$. $\dagger p$ Value for trend over time.

women who had an unclear, unclassifiable occupation increased during the study period. An increase was also observed in the proportions of students (from 5\% to 8\%) and unemployed women (from $0.2 \%$ to $0.6 \%$ ), while the proportion of housewives increased at first, but levelled off to $7 \%$ in the late 1990s (table 1).

\section{Differences by socioeconomic group}

There were substantial differences in the maternal background characteristics by socioeconomic group. Upper white collar workers (SES Group I) were almost two years older than lower white collar workers (SES Group II), more than three years older than blue collar workers (SES Group III), and more than four years older than the women in the SES Group "Others". There was the least number of single mothers in SES Group I (5\%) and the most in SES Group III (13\%). In total $26 \%$ of women in SES Group III smoked during pregnancy, while smoking was much less frequent in SES Groups II (13\%) and I (5\%). The number of previous pregnancies and deliveries was highest in the SES Group "Others", but otherwise a clear reversed gradient was observed. The proportion of multiple births was highest in SES Group I (table 2).

In all socioeconomic groups the trends in maternal background factors were similar for mean maternal age (increased) and the proportion of single mothers (first increased, then decreased). The mean number of previous pregnancies and deliveries increased by $8 \%$ to $10 \%$ in SES Groups II and III, remained at the same level in SES Group I, but decreased by more than $10 \%$ in the SES Group "Others". The prevalence of smokers decreased by $13 \%$ to $14 \%$ in SES Groups II and III and by $26 \%$ in SES Group I, but remained at the same level for the SES Group "Others". The number of multiple births increased more for SES Groups I-III (34\% to $40 \%)$ than in the SES Group "Others" (10\%), but the BreslowDay test for time trends remained insignificant (table 2).

A clear gradient in favour of the highest socioeconomic group was found for SES Groups I to III for all selected infant outcomes, while the mixed SES Group "Others" fell between the two extremes. An exception was perinatal mortality, for which the SES Group "Others" had the poorest outcome (table 
Table 3 Perinatal outcome by socioeconomic group, Finland, 1991-1999 ( $n=565863)$ *

\begin{tabular}{|c|c|c|c|c|c|c|}
\hline Children & & Total & Unadjusted OR§̧ & Adjusted OR, Model II & Adjusted OR, Model II** & $\begin{array}{l}\text { Explanation } \\
\text { percentage for } \\
\text { smoking }\end{array}$ \\
\hline Number & & 565863 & 548913 & 548913 & 548913 & \\
\hline \multicolumn{7}{|l|}{ Prematurity, \%† } \\
\hline Upper white collar workers & 1 & 5.0 & 1.00 & 1.00 & 1.00 & \\
\hline Lower white collar workers & $\|$ & 5.2 & 1.02 (0.99 to 1.06$)$ & 1.11 (1.05 to 1.18$)$ & 1.09 (1.06 to 1.13$)$ & 18 \\
\hline Blue collar workers & III & 5.5 & 1.09 (1.05 to 1.14$)$ & 1.35 (1.25 to 1.45$)$ & 1.20 (1.15 to 1.25$)$ & 42 \\
\hline Others & $\mathrm{O}$ & 5.1 & 0.98 (0.95 to 1.02$)$ & 1.30 (1.20 to 1.40$)$ & 1.23 (1.18 to 1.28$)$ & 22 \\
\hline \multicolumn{7}{|l|}{ Low birth weight, \%‡ } \\
\hline Upper white collar workers & 1 & 4.0 & 1.00 & 1.00 & 1.00 & \\
\hline Lower white collar workers & $\|$ & 4.2 & 1.03 (0.99 to 1.07$)$ & 1.20 (1.10 to 1.27$)$ & $1.11(1.06$ to 1.15$)$ & 48 \\
\hline Blue collar workers & III & 4.6 & 1.16 (1.11 to 1.22 ) & 1.42 (1.35 to 1.49$)$ & 1.25 (1.19 to 1.31$)$ & 41 \\
\hline Others & 0 & 4.1 & 1.01 (0.97 to 1.06$)$ & 1.41 (1.35 to 1.48 ) & 1.31 (1.24 to 1.37$)$ & 26 \\
\hline \multicolumn{7}{|l|}{ Small for gestational age, $\%$} \\
\hline Upper white collar workers & 1 & 2.1 & 1.00 & 1.00 & 1.00 & \\
\hline Lower white collar workers & II & 2.3 & 1.07 (1.01 to 1.13$)$ & 1.20 (1.14 to 1.27$)$ & 1.11 (1.05 to 1.17$)$ & 46 \\
\hline Blue collar workers & III & 2.8 & 1.30 (1.22 to 1.38$)$ & 1.57 (1.48 to 1.67$)$ & 1.28 (1.20 to 1.37$)$ & 51 \\
\hline Others & 0 & 2.3 & 1.04 (0.98 to 1.11$)$ & 1.46 (1.37 to 1.55$)$ & 1.29 (1.17 to 1.37$)$ & 37 \\
\hline \multicolumn{7}{|l|}{ Perinatal mortality, 1/1000 } \\
\hline Upper white collar workers & I & 5.6 & 1.00 & 1.00 & 1.00 & \\
\hline Lower white collar workers & $\|$ & 6.2 & 1.10 (0.99 to 1.22$)$ & 1.18 (1.06 to 1.31$)$ & 1.15 (1.04 to 1.28 ) & 15 \\
\hline Blue collar workers & III & 7.4 & 1.32 (1.18 to 1.49 ) & 1.50 (1.33 to 1.60$)$ & 1.41 (1.25 to 1.59$)$ & 18 \\
\hline Others & 0 & 8.1 & $1.42(1.27$ to 1.58$)$ & 1.49 (1.32 to 1.67$)$ & 1.43 (1.27 to 1.62$)$ & 11 \\
\hline
\end{tabular}

3). Similar results were found when only including singletons in the analysis (data not shown).

Adjusting for background variables in multiple logistic regression increased the differences between the socioeconomic groups as the biological background variablesespecially maternal age-were in favour of the lower socioeconomic groups. The risk for women in SES Group III to have a premature birth was 35\% higher than in SES Group I. The relative risk was even higher for other variables: $42 \%$ for having a low birthweight infant, $50 \%$ for perinatal mortality and $57 \%$ for having a SGA infant (table 3 ).

When including smoking in the logistic regression models, the excess risk for adverse perinatal outcome was reduced most for SES Group III and least for the SES Group "Others". Smoking explained up to half of the socioeconomic differences in variables related to birth weight, but less than one fifth of those in perinatal mortality (table 3 ).

The time trends in infant outcome were divergent. The proportions of premature births, low birthweight infants, and SGA infants increased and the mean birth weight decreased, but on the other hand the perinatal mortality rate decreased (table 4). The time trends differed by socioeconomic group: the highest socioeconomic groups as well as the SES Group "Others" followed the general pattern of deterioration, while the infant outcome in SES Group III improved. An exception was perinatal mortality, which remained unchanged in the highest socioeconomic group, but decreased in all other groups.

After adjusting for maternal background characteristics the differences between SES Groups I and II remained at the same level and remained statistically significant over the study period. This was true for all outcome variables excluding perinatal mortality, for which the differences between 1994 and 1996 and between 1997 and 1999 became statistically insignificant. When comparing SES Group III to SES Group I, the excess risk for prematurity and that for low birth weight halved from $32 \%$ to $16 \%$ and from $49 \%$ to $25 \%$, respectively; the decrease was even larger for perinatal mortality, from 79\% to $33 \%$, but there was no change in the risk of having an SGA infant. The difference between SES Group I and the SES Group "Others" remained statistically significant for all outcome variables excluding perinatal mortality, for which a decrease in the difference was observed (table 4).

\section{DISCUSSION}

Socioeconomic differences were observed for all variables measuring perinatal outcome. Against our hypothesis, these differences decreased for all perinatal health indicatorsexcept for tSGA-during the 1990s, even though Finland faced a severe economic recession that led to reduced social welfare benefits ${ }^{25}$ and subsequently to increased income differences. ${ }^{7}$ Our results also deviate from the widening mortality differences ${ }^{8}$ and unchanged morbidity differences ${ }^{9}$ observed among the general population in Finland, and from the widening socioeconomic differences in perinatal health in other countries (for example, in the United States ${ }^{26}$ ).

Two developments were uncovered. Firstly, the proportion of newborns with adverse infant outcome increased among the whole population, but especially in the highest socioeconomic groups. This can partly be explained by the increase in some maternal risk factors among upper white collar women: the mean maternal age increased because of further postponed childbearing, ${ }^{27}$ and the proportion of multiple births increased. ${ }^{28}$ The latter may be attributable to more intensive use of advanced infertility treatments.

Secondly, the newborns of the mothers in the lowest socioeconomic group had less adverse outcomes over time. This trend was not explained by maternal risk factors included in our study, and the changes in other background variables were not in favour of the lowest socioeconomic group, as the example of maternal smoking shows. We could find no reason for the both absolute and relative improvement in the lowest socioeconomic group. One explanation could be the change in the composition of occupations. As in the general population, the percentage of women in the highest socioeconomic group increased, and the proportion of women in the two lower socioeconomic groups declined. It is, however, unlikely that these changes could explain our results, because the relative changes in the sizes of the groups were relatively small.

The proportion of women in the SES Group "Others" increased from $19 \%$ to $26 \%$ during the study period, largely because of the increasing number of women with no indicated occupation (accounting for 39\% of the increase) or with an unclassifiable occupation (15\%). However, less than one tenth of the alterations in perinatal outcome over time would be explained if women without health problems moved from the 
Table 4 Perinatal outcome by socioeconomic group and by time, Finland, 1991-1999 (n=563952)*

\begin{tabular}{|c|c|c|c|c|c|c|c|c|}
\hline & & \multirow[b]{2}{*}{$\begin{array}{l}1991- \\
1993\end{array}$} & \multirow[b]{2}{*}{$\begin{array}{l}1994- \\
1996\end{array}$} & \multirow[b]{2}{*}{$\begin{array}{l}1997- \\
1999\end{array}$} & \multirow[b]{2}{*}{$\mathrm{p} \dagger$} & \multicolumn{3}{|l|}{ Adjusted OR $\ddagger$} \\
\hline & & & & & & $1991-1993$ & 1994-1996 & 1997-1999 \\
\hline Number & & 199289 & 190839 & 175735 & & 193924 & 185052 & 169937 \\
\hline \multicolumn{9}{|l|}{ Prematurity, \% } \\
\hline Upper white collar workers & 1 & 4.9 & 4.9 & 5.2 & 0.352 & 1.00 & 1.00 & 1.00 \\
\hline Lower white collar workers & $\|$ & 5.1 & 5.1 & 5.3 & 0.506 & $\begin{array}{l}1.13 \\
(1.06 \text { to } 1.21)\end{array}$ & $\begin{array}{l}1.16 \\
(1.09 \text { to } 1.23)\end{array}$ & $\begin{array}{l}1.10 \\
(1.03 \text { to } 1.17)\end{array}$ \\
\hline Blue collar workers & III & 5.6 & 5.6 & 5.4 & 0.012 & $\begin{array}{l}1.32 \\
(1.24 \text { to } 1.43)\end{array}$ & $\begin{array}{l}1.32 \\
(1.24 \text { to } 1.43)\end{array}$ & $\begin{array}{l}1.16 \\
(1.08 \text { to } 1.25)\end{array}$ \\
\hline \multirow[t]{2}{*}{ Others } & O & 5.0 & 5.0 & 5.2 & 0.778 & $\begin{array}{l}1.27 \\
(1.17 \text { to } 1.38)\end{array}$ & $\begin{array}{l}1.33 \\
(1.24 \text { to } 1.43)\end{array}$ & $\begin{array}{l}1.25 \\
(1.17 \text { to } 1.34)\end{array}$ \\
\hline & Total & 5.1 & 5.1 & 5.3 & 0.469 & & & \\
\hline \multicolumn{9}{|l|}{ Low birth weight, $\%$} \\
\hline Upper white collar workers & I & 3.8 & 4.0 & 4.4 & 0.206 & 1.00 & 1.00 & 1.00 \\
\hline Lower white collar workers & ॥ & 3.9 & 4.2 & 4.4 & 0.021 & $\begin{array}{l}1.14 \\
(1.05 \text { to } 1.24)\end{array}$ & $\begin{array}{l}1.21 \\
(1.12 \text { to } 1.30)\end{array}$ & $\begin{array}{l}1.16 \\
(1.08 \text { to } 1.24)\end{array}$ \\
\hline Blue collar workers & III & 4.6 & 4.8 & 4.5 & 0.003 & $\begin{array}{l}1.49 \\
(1.36 \text { to } 1.63)\end{array}$ & $\begin{array}{l}1.52 \\
(1.40 \text { to } 1.66)\end{array}$ & $\begin{array}{l}1.25 \\
(1.17 \text { to } 1.40)\end{array}$ \\
\hline \multirow[t]{2}{*}{ Others } & O & 3.9 & 4.1 & 4.2 & 0.836 & $\begin{array}{l}1.36 \\
(1.23 \text { to } 1.50)\end{array}$ & $\begin{array}{l}1.49 \\
(1.37 \text { to } 1.62)\end{array}$ & $\begin{array}{l}1.37 \\
(1.26 \text { to } 1.49)\end{array}$ \\
\hline & Total & 4.0 & 4.2 & 4.4 & 0.126 & & & \\
\hline \multicolumn{9}{|l|}{ SGA, \% } \\
\hline Upper white collar workers & I & 2.1 & 2.1 & 2.2 & 0.610 & 1.00 & 1.00 & 1.00 \\
\hline Lower white collar workers & $\|$ & 2.2 & 2.3 & 2.5 & 0.424 & $\begin{array}{l}1.14 \\
(1.03 \text { to } 1.26)\end{array}$ & $\begin{array}{l}1.24 \\
(1.13 \text { to } 1.37)\end{array}$ & $\begin{array}{l}1.19 \\
\text { (1.09 to } 1.31)\end{array}$ \\
\hline Blue collar workers & III & 2.8 & 2.7 & 2.8 & 0.235 & $\begin{array}{l}1.44 \\
(1.30 \text { to } 1.63)\end{array}$ & $\begin{array}{l}1.69 \\
(1.51 \text { to } 1.89)\end{array}$ & $\begin{array}{l}1.45 \\
(1.34 \text { to } 1.66)\end{array}$ \\
\hline \multirow[t]{2}{*}{ Others } & O & 2.2 & 2.2 & 2.4 & 0.829 & $\begin{array}{l}1.20 \\
(1.07 \text { to } 1.36)\end{array}$ & $\begin{array}{l}1.59 \\
(1.42 \text { to } 1.78)\end{array}$ & $\begin{array}{l}1.39 \\
(1.25 \text { to } 1.55)\end{array}$ \\
\hline & Total & 2.3 & 2.3 & 2.5 & 0.342 & & & \\
\hline \multicolumn{9}{|l|}{ Perinatal mortality, $1 / 1000$} \\
\hline Upper white collar workers & I & 5.7 & 5.4 & 5.6 & 0.258 & 1.00 & 1.00 & 1.00 \\
\hline Lower white collar workers & $\|$ & 6.8 & 5.9 & 5.8 & 0.333 & $\begin{array}{l}1.38 \\
(1.14 \text { to } 1.68)\end{array}$ & $\begin{array}{l}1.14 \\
(0.95 \text { to } 1.37)\end{array}$ & $\begin{array}{l}1.08 \\
(0.89 \text { to } 1.30)\end{array}$ \\
\hline Blue collar workers & III & 8.3 & 7.1 & 6.8 & 0.794 & $\begin{array}{l}1.79 \\
(1.44 \text { to } 2.21)\end{array}$ & $\begin{array}{l}1.50 \\
(1.22 \text { to } 1.85)\end{array}$ & $\begin{array}{l}1.33 \\
(1.07 \text { to } 1.66)\end{array}$ \\
\hline \multirow[t]{2}{*}{ Others } & O & 9.0 & 8.6 & 6.5 & 0.012 & $\begin{array}{l}1.81 \\
(1.46 \text { to } 2.26)\end{array}$ & $\begin{array}{l}1.57 \\
(1.27 \text { to } 1.93)\end{array}$ & $\begin{array}{l}1.33 \\
(1.08 \text { to } 1.64)\end{array}$ \\
\hline & Total & 7.3 & 6.6 & 6.1 & 0.088 & & & \\
\hline \multicolumn{9}{|l|}{ Birth weight, mean and SD, g } \\
\hline & 1 & 3554576 & 3550580 & 3524584 & 0.340 & & & \\
\hline & ॥ & 3555587 & 3543591 & 3524594 & 0.129 & & & \\
\hline & III & 3518605 & 3514606 & 3499594 & 0.272 & & & \\
\hline & O & 3541603 & 3525601 & 3505594 & 0.057 & & & \\
\hline & Total & 3545592 & 3535594 & 3515592 & 0.169 & & & \\
\hline
\end{tabular}

*All differences between the socioeconomic groups are statistically significant, $p<0.001$. See also table 3 . $\nmid p$ Value for test for trend over time. $\ddagger$ Adjusted by maternal age, parity, and county of residence. Singletons only.

highest socioeconomic group to the SES Group "Others" over time, and at the same time women with health problems moved from the lowest group to the SES Group "Others". Unemployment and avoidance of harmful work exposure, increased knowledge about preventive and health promoting behaviour, and improved prenatal and delivery care are further hypothetical explanations.

Previous Finnish studies on socioeconomic differences in perinatal health that have used socioeconomic position based on maternal occupation have studied perinatal mortality only. The unadjusted OR in this study ( 1.50 with $95 \%$ confidence intervals 1.33 to 1.60 , see table 3 ) is comparable to those observed in other studies: 1.35 to $1.55 .{ }^{629}{ }^{30}$ Previous Finnish studies on perinatal health by education ${ }^{3}$ and by marital position $^{2}$ from the late 1980s have reported larger socioeconomic differences than observed in our study. A more recent study combining the 1991 MBR with the Education Register ${ }^{4}$ reported higher socioeconomic differences for prematurity (adjusted OR with 95\% confidence intervals 1.67 ( 1.47 to 1.89) $v 1.32$ ( 1.24 to 1.43$)$ ) and for low birth weight (2.09 (1.78 to 2.49) $v 1.49$ (1.36 to 1.63)) than did our 1991-1993 data, as shown in table 4 . For perinatal mortality, the ORs were similar: ( 1.85 ( 1.33 to 2.57$) v 1.79$ ( 1.44 to 2.21$)$ ). This suggests that socioeconomic differences may be more prominent when investigated by education or marital status than by occupation.

Beside the general importance of promoting equity in health in all age groups, the lessening of inequalities in perinatal health is especially important because of the theoryeven though controversial-suggesting that health problems in utero and right after birth are related to several major diseases in adulthood. ${ }^{31}{ }^{32}$ Socioeconomic health differences in early life may manifest as even larger differences in adulthood. The known behavioural risk factors, such as smoking and 


\section{Key points}

- Monitoring of socioeconomic differences over time is important, but it can seldom be done routinely.

- This article shows that a routinely collected administrative register can include a measurement of socioeconomic status.

- Socioeconomic differences in perinatal health still exit in Finland, but our data suggest that they have decreased in the 1990s.

- Smoking explains up to half of adverse perinatal outcome among mothers in the lowest socioeconomic group.

unhealthy diet, are over-represented among the lower socioeconomic groups, ${ }^{33}{ }^{34}$ and it has been suggested that conditions like economic hardship, poor living conditions, low social support, and other social problems in early life may be connected with poor adult health. ${ }^{35} 36$

Our data showed that up to half of the differences in the adverse perinatal outcome could be explained by maternal smoking. This is in accordance with a previous observational study in Finland. ${ }^{37}$ But this need not mean that the observed effect is directly causal: smokers may also have other characteristics or circumstances, not measured in the MBR data, which may have contributed to the adverse outcome. Smoking cessation trials, however, have benefits for the infants. ${ }^{38}$ These trials support the notion that maternal smoking causes adverse perinatal outcomes.

An essential requirement for our conclusions is that the register information be of high quality. This has been shown for occupational data in the Finnish MBR. ${ }^{17}$ The national classifications on occupations and socioeconomic position were updated in $1997,{ }^{39}$ but they have not been implemented in the MBR because such changes tend to be costly and time consuming. This may not, however, affect our results as the socioeconomic position was categorised in four broad groups, minimising the effect of modified classifications.

During the 1990s, the Finnish labour market underwent a major structural change, and this may have affected the collection of socioeconomic data that uses maternal occupation. So called "atypical work contracts" have become more common: young people-especially young women of reproductive age-do not receive permanent work contracts, but short-term ones only. There is no evidence about how this affects the collection of occupational data. It is probable that this may increase the number of women with hard to classify work situations, especially if short-term work contracts are followed by a period of unemployment or further education. Thus, our finding of decreasing socioeconomic differences in perinatal health has to be verified by data linkages with other (register based) data on socioeconomic position.

Ideally, information gathered on occupation would also include data on the working place. However, it is unrealistic to attempt to gather reliable information on both occupation and the work place in routine data collection, the primary aim of which is to collect medical information. We doubt that the collection of reliable information on health by disposable income-as proposed by the European Parliament and the Commission of the European Communities ${ }^{40}$ - can be done routinely, but the example of Estonia shows that the collection of information on completed education can be feasible as regards a nationwide $\mathrm{MBR}^{4}$

Previous Finnish studies have reported that mothers' socioeconomic position is a more powerful indicator of health inequalities than is fathers' socioeconomic position, ${ }^{42}$ but information on fathers' socioeconomic position could be used to get a more complete picture on socioeconomic circumstances. In Finland, information on husbands and on men who have confirmed their fatherhood in a juridical process ${ }^{43}$ can be obtained from the Central Population Register for ad hoc research, but not for routine surveillance. Also the use of general social assistance can be used as a surrogate socioeconomic measurement indicating economic hardship and/or poverty in Finland, because both the applicant's and his/her spouse's identification numbers are available at national level.

To conclude, in Finland routine register data can be used in monitoring socioeconomic differences in perinatal health. Our data collection method would be important for countries where data linkages between different registers are prohibited or where the lack of unique identification numbers makes such linkages complex and time consuming. To minimise systematic bias related to our data collection method, the validity of our data as well as our results on decreasing socioeconomic differences should be verified by data linkages to other data sources.

\section{Authors' affiliations}

M Gissler, J Meriläinen, E Vuori, E Hemminki, National Research and Development Centre for Welfare and Health, Finland

\section{REFERENCES}

1 Lahelma E, Lundberg $O$, Manderbacka K, et al. Changing health inequalities in the Nordic countries. Scand J Public Health 2001:29 (suppl 55): 1-5

2 Manderbacka K, Meriläinen J, Hemminki E, et al. Marital status as a predictor of perinatal outcome in Finland. Journal of Marriage and Family 1992:54:508-15.

3 Hemminki E, Meriläinen J, Malin M et al. Mother's education and perinatal problems in Finland. Int J Epidemiol 1992;21:720-4.

4 Gissler M, Hemminki E, Meriläinen J, et al. Äidin koulutus ja perinataaliajan ongelmat [Maternal education and perinatal problems, Abstract in Finnish]. Sosiaalilääket Aikakausl 1995:32:377.

5 Gissler M, Rahkonen O, Järvelin M-R, et al. Social class differences in health until the age of seven years among the Finnish 1987 birth cohort. Soc Sci Med 1998;46:1543-52.

6 Forssas E, Gissler M, Sihvonen M, et al. Maternal predictors of perinatal mortality - the role of birth weight. Int J Epidemiol 1999:28:475-8.

7 Statistics Finland. Income distribution statistics 1999. Income and consumption 16. Helsinki: Statistics Finland, 2001

8 Martikainen P, Valkonen T, Martelin T. Change in male and female life expectancy by social class: decomposition by age and cause of death in Finland 1971-95. J Epidemiol Community Health 2001:55:494-9.

9 Manderbacka K, Lahelma E, Rahkonen O. Structural changes and social inequalities in health in Finland, 1986-1994. Scand J Public Health 2001;29 (suppl 55):41-54.

10 Gissler M, Järvelin M-R, Hemminki E. Children's health in Northern Finland-a comparison of cohort and register based studies. Eur J Epidemiol 2000; 16:59-66.

11 Gissler M, Louhiala P, Hemminki E. Nordic medical birth registers in epidemiological research. Eur J Epidemiol 1997;13:169-75.

12 Gissler M. Administrative registers in health research-a cohort study of Finnish children born in 1987. Jyräskyä: STAKES Research Report 97 1999. [Doctoral thesis.]

13 Keskimäki I, Aro S. Accuracy of data on diagnoses, procedures and accidents in the Finnish Hospital Discharge Register. Int J Health Sci 1991;2:15-21.

14 Keskimäki I, Salinto M, Aro S. Socioeconomic equity in Finnish hospital care in relation to need. Soc Sci Med 1995;41:425-31.

15 Keskimäki I, Koskinen S, Salinto $M$, et al. Socioeconomic and gender inequities in access to coronary artery bypass grafting in Finland. Eur Public Health 1997:7:392-7.

16 Gissler M, Hemminki E, Louhiala P, et al. Health registers as a feasible means of measuring health status in childhood-a 7-year follow-up of the 1987 Finnish birth cohort. Paediatr Perinat Epidemiol 1998;12:437-55.

17 Gissler M, Teperi J, Hemminki E, et al. Data quality after restructuring a nationwide medical birth registry. Scand J Soc Med 1995;23:75-80.

18 Gissler M, Ollila E, Teperi J, et al. Impact of induced abortions and statistical definitions on perinatal mortality figures. Pediatr Perinat Epidemiol 1994;8:391-400

19 Gissler M, Teperi J, Forssas E, et al. Syntymärekisterin luotettavuustutkimus 1991 [The data quality of the Medical Birth Register in Finnish]. Helsinki: Stakes Aiheita 11/1993.

20 Statistics Finland. Classification of occupations. Handbooks 14. Helsinki: Statistics Finland, 1987

21 Statistics Finland. Classification of socioeconomic groups. Handbooks 17. Helsinki: Statistics Finland, 1989

22 Statistics Finland. Koulutusluokitus 31.12.1991 [Classification of education 31 December 1991] Handbooks 1. Helsinki: Statistics Finland, 1992.

23 Pihkala J, Hakala T, Voutilainen P, et al. Uudet suomalaiset sikiön kasvukäyrät [Characteristics of recent fetal growth curves in Finland, in Finnish]. Duodecim 1989;105:1540-6. 
24 van de Mheen $\mathbf{H}$, Stronks J, van den Bos J, et al. The contribution of childhood environment to the explanation of socioeconomic inequalities in health in adult life: a retrospective study. Soc Sci Med 1997;44:13-24

25 Kautto M, Heikkilä M, Hvinden B, et al. Nordic social policy: changing welfare states. London: Routledge, 1999

26 Mathews TJ, Menacker F, MacDorman MF. Infant mortality statistics from the 200 period linked birth/infant death data set. Hyattsville: National vital statistics reports, vol 50, no 12, 2002

27 Hemminki E, Gissler M. Births of young and old mothers in a population of late and regulated childbearing: Finland 1991. Acta Obstetr Gynecol Scand 1996;75:19-27.

28 Gissler $M$, Tiitinen A. IVF treatments and their outcome in Finland in the 1990s. Acta Obstetr Gynecol Scand 2001:80:937-44.

29 Notkola V Valkonen T. Kuolleena syntyneisyyden sekä imeväiskuolleisuuden sosioekonomiset erot Suomessa 1976-1982 [The socioeconomic differences in stillbirths and infant deaths in Finland 1976-1982, in Finnish with abstract in English]. Sosiaalilääket aikakausl 1990;27:17-22

30 Valkonen T, Martelin T, Rimpelä A, et al. Socioeconomic mortality differences in Finland 1981-1990. Finnish Official Statistics: Population 1: 1993. Helsinki: Statistics Finland, 1993.

31 Barker D, ed. Fetal and infant origins of adult disease. Plymouth: British Medical Journal, 1992

32 Barker D. Mother's, babies and diseases in later life. Plymouth: British Medical Journal, 1994

33 Rahkonen O, Puska P, Berg M-A. Relationship between educational status, gender and smoking in Finland, 1978-1992. Health Prom Int 1995; 10:115-20.
34 Sarlio-Lähteenkorva S, Lahelma E. The association of body mass index with social and economic disadvantages in women and men. Int $J$ Epidemiol 1999;28:445-9.

35 Vågerö D, Illsley R. Explaining health inequalities. Beyond Black and Barker. Eur Sociol Rev 1996;11:219-41.

36 Wadsworth MEJ. Health inequalitites in the life course perspective. Soc Sci Med 1997;44:859-69.

37 Jaakkola N, Jaakkola $M$, Gissler $M$, et al. Smoking during pregnancy in Finland: determinants and trends from 1987 and 1997. Am J Public Health 2001;91:284-6.

38 Jaakkola N. Passive smoking during pregnancy and early childhood. Occurrence, determinants, health effects and prevention. University of Helsinki, Department of Public Health M: 179. Helsinki: Yliopistopaino, 2002.

39 Statistics Finland. Luokitukset [Classifications, in Finnish] http://www.tilastokeskus.fi/tk/tt/luokitukset/index.html (accessed 8 January 2002)

40 Commission of the European Communities. Amended proposal for a decision of the European Parliament and of the Council adopting a programme of Community action in the field of public health (2001-2006). COM(2001)302 final. http://europa.eu.int/comm/ health/ph/key_doc/ke05_en.pdf (accessed 10 Feb 2002)

41 Innos K, Rahu M. Epidemiological data sources in Estonia: a survey of registries and databases. J Epidemiol Biostat 2000;5:293-302.

42 Rantakallio P. Social background of mothers who smoked during pregnancy and their influence on the offspring. Soc Sci Med 1979;13A:423-9.

43 STAKES. Statistical yearbook on social welfare and health care 2000 Helsinki: Finnish Official Statistics: Social security 1:2001.

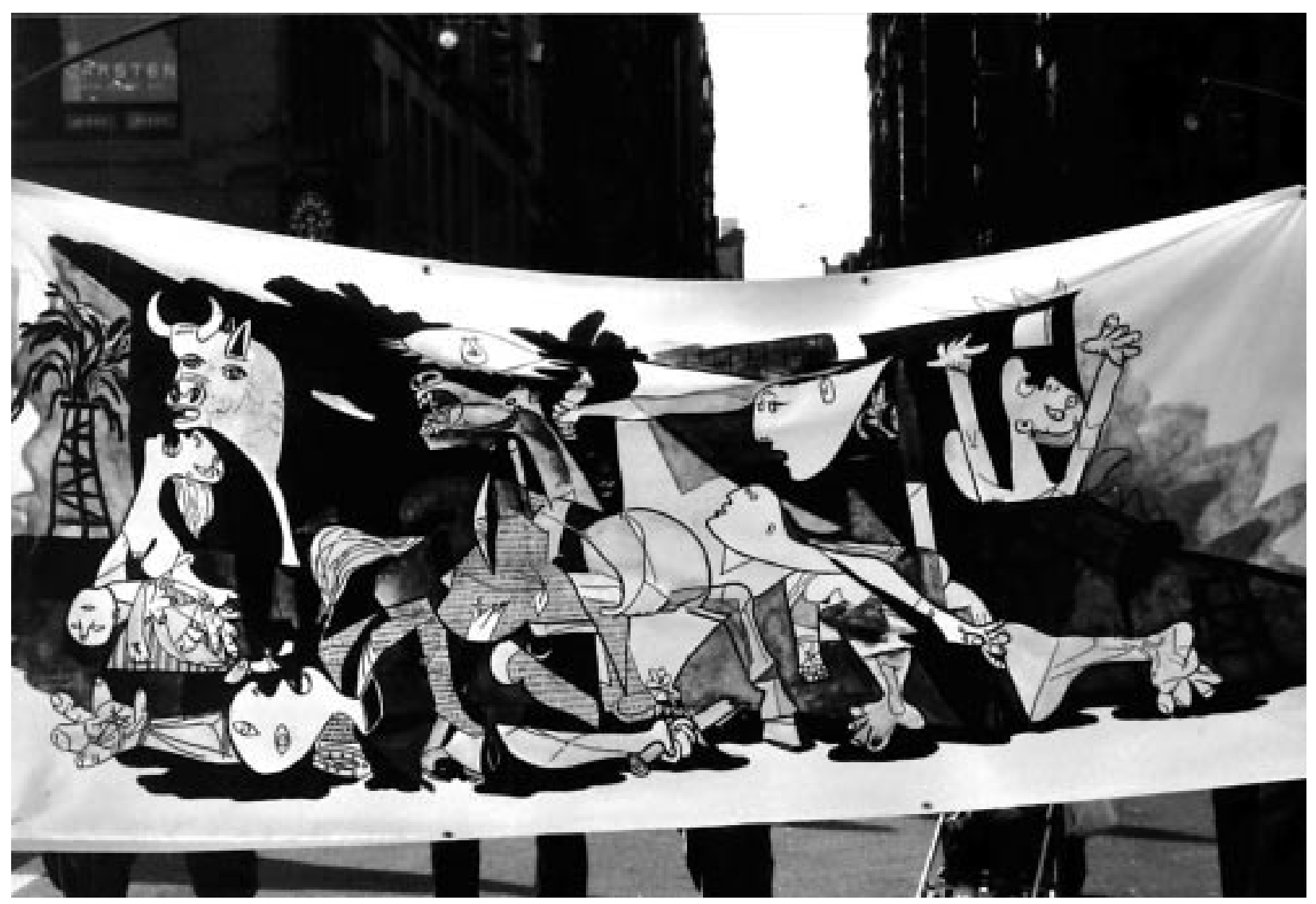

Guernica revisited in New York, USA, 2003. 